\title{
Inhibition of gluconeogenesis by hypoglycin in the rat
}

\author{
Evidence for inhibition of glucose-6-phosphatase in vivo
}

\author{
Louis HUE* and H. Stanley A. SHERRATT $\dagger$ \\ Laboratoire de Chimie Physiologique, University of Louvain, and International Institute of Cellular and Molecular Pathology, \\ UCL 7539, Avenue Hippocrate 75, B-1200 Brussels, Belgium
}

\begin{abstract}
Treatment of rats with hypoglycaemic doses of hypoglycin has been shown to abolish the relative detritiation of $\left[2-{ }^{3} \mathrm{H}, \mathrm{U}-{ }^{14} \mathrm{C}\right]$ glucose [Osmundsen, Billington, Taylor \& Sherratt (1978) Biochem. J. 170, 337-342], indicating that both the Cori and the glucose/glucose 6-phosphate cycles were inhibited in vivo. This inhibition was confirmed and, in addition, it was shown that the conversion in vivo of both $\left[{ }^{14} \mathrm{C}\right]$ lactate and $\left[{ }^{14} \mathrm{C}\right]$ fructose into glucose was decreased after hypoglycin treatment. These results suggest that hypoglycin poisoning results in the inhibition in vivo of glucose-6-phosphatase activity, which participates in the overall inhibition of gluconeogenesis and hypoglycaemia. Clofibrate feeding apparently protected the rats against the inhibition of the fructose-to-glucose conversion by hypoglycin. However, in isolated hepatocytes prepared from hypoglycin-treated rats, the conversion of $\left[{ }^{14} \mathrm{C}\right]$ fructose into glucose and the recycling of $\left[2-{ }^{3} \mathrm{H}, \mathrm{U}-{ }^{14} \mathrm{C}\right]$ glucose were not different from that in control hepatocytes. This suggests that the inhibition was lost during preparation of the hepatocytes. The direct measurement of glucose-6-phosphatase activity showed that it was inhibited when measured in concentrated, but not dilute, homogenates prepared from hypoglycin-treated rats.
\end{abstract}

\section{INTRODUCTION}

Hypoglycin (1-amino-3-methylenecyclopropanepropionic acid) is the toxic hypoglycaemic amino acid of the Jamaican ackee fruit Blighia sapida. Its metabolite, methylenecyclopropylacetyl-CoA, inhibits the $\beta$-oxidation of fatty acids and the degradation of leucine and isoleucine in liver (Sherratt, 1969, 1981; Sherratt et al., 1985). This, in turn, causes the accumulation of CoA derivatives, which inhibit pyruvate carboxylase by competition with acetyl-CoA, a potent stimulator of this enzyme (Scrutton \& Griffiths, 1981). This indirect inhibition of pyruvate carboxylase explains why, in isolated hepatocytes, hypoglycin inhibits gluconeogenesis from substrates entering the pathway at the level of pyruvate, but not from substrates entering at the level of triose phosphates (Sherratt, 1981; Stirk et al., 1983; Sherratt et al., 1985).

In addition, Osmundsen et al. (1978) showed that, after treatment of rats with hypoglycaemic doses of hypoglycin, the rate of irreversible disposal of $\left[2-{ }^{3} \mathrm{H}\right]-$ glucose was not different from that of $\left[\mathrm{U}-{ }^{14} \mathrm{C}\right]$ glucose, and they concluded that recycling of glucose through the Cori cycle was virtually abolished. The loss of ${ }^{3} \mathrm{H}$ from C-2 of glucose occurs at the level of hexose 6-phosphate in the reaction catalysed by phosphohexose isomerase. In the intact animal, relative detritiation of $\left[2-{ }^{3} \mathrm{H}, \mathrm{U}-{ }^{14} \mathrm{C}\right]-$ glucose occurs not only through the complete cycling of glucose via the Cori cycle, as Osmundsen et al. (1978) assumed, but also in the glucose/glucose 6-phosphate cycle in the liver (Katz \& Rognstad, 1976; Hue, 1981). Even a complete block in gluconeogenesis, e.g. at the level of pyruvate carboxylase, would not abolish the relative detritiation of $\left[2-{ }^{3} \mathrm{H}, \mathrm{U}-{ }^{14} \mathrm{C}\right]$ glucose, since the glucose/glucose 6-phosphate cycle would still persist. Therefore the absence of relative detritiation of $\left[2-{ }^{3} \mathrm{H}, \mathrm{U}-{ }^{14} \mathrm{C}\right]$ glucose after hypoglycin treatment suggests that, on top of the already suspected inhibition of pyruvate carboxylase, the glucose/glucose 6-phosphate cycle could also have been inhibited in vivo. This may result from inhibition of glucokinase, glucose 6phosphatase or phosphohexose isomerase. Inhibition of detritiation of $\left[2-{ }^{3} \mathrm{H}, \mathrm{U}-{ }^{14} \mathrm{C}\right]$ glucose has indeed been observed in patients suffering from Type I glycogenstorage disease (Van Hoof et al., 1972; Hue, 1981), a condition characterized by a deficiency in glucose6-phosphatase.

The mechanism of inhibition of gluconeogenesis and of glucose/glucose 6-phosphate cycling by hypoglycin in intact rats was therefore re-investigated and compared with inhibition in isolated hepatocytes. This paper presents some indirect evidence for the inhibition of glucose-6-phosphatase by hypoglycin in vivo. The inhibition was reversible and did not occur in isolated liver cells.

\section{MATERIALS AND METHODS}

\section{Materials}

Radioactive compounds were obtained from The Radiochemical Centre, Amersham, Bucks., U.K. Enzymes and biochemical reagents were either from Sigma (St. Louis, MO, U.S.A.) or from Boehringer (Mannheim, Germany). Glucagon was from Novo Industri (Copenhagen, Denmark). Hypoglycin (85\% pure) was prepared from ackee seeds as described by

\footnotetext{
* Present address: Hormone and Metabolic Research Unit, ICP-UCL 7529, Avenue Hippocrate 75, B-1200 Brussels, Belgium.

$\dagger$ Permanent address: Department of Pharmacological Sciences, Medical School, University of Newcastle upon Tyne, Newcastle upon Tyne NE2 4HH, U.K.
} 
Billington \& Sherratt (1981). Clofibrate was a gift from I.C.I. plc (Macclesfield, Cheshire, U.K.)

\section{Experiments in vivo}

Adult male Wistar rats (about $250 \mathrm{~g}$ ) were fasted for $9 \mathrm{~h}$ and then given either $0.15 \mathrm{M}-\mathrm{NaCl}$ or hypoglycin $(70 \mathrm{mg} / \mathrm{kg}$ body wt.) as a $1 \%(\mathrm{w} / \mathrm{v})$ solution in $0.15 \mathrm{M}-\mathrm{NaCl}$ intraperitoneally $16 \mathrm{~h}$ before being used. The rats were then anaesthetized (Nembutal, $50 \mathrm{mg} / \mathrm{kg}$ intraperitoneally), the abdomen was opened and the liver was quick-frozen (Wollenberger et al., 1960) for the determination of metabolites and enzyme activities. For measurement of the ${ }^{3} \mathrm{H} /{ }^{14} \mathrm{C}$ ratio in blood glucose, the animals were given $\left[2-{ }^{3} \mathrm{H}, \mathrm{U}-{ }^{-14}\right]$ glucose $(10 \mu \mathrm{Ci} / \mathrm{kg}$ body wt) intraperitioneally, and blood samples were taken from the vena cava after $60 \mathrm{~min}$. Blood was collected in heparinized syringes, and deproteinized (Weichselbaum \& Somogyi, 1941). The ${ }^{3} \mathrm{H} /{ }^{14} \mathrm{C}$ ratio in blood glucose was determined as described previously (Van Hoof et al., 1972; Hue \& Hers, 1974).

For the measurement of the conversion in vivo of $\left[\mathrm{U}-{ }^{14} \mathrm{C}\right]$ fructose into glucose, rats were anaesthetized and heparinized, and a cannula was secured in the vena cava. Radioactive fructose ( $5 \mu \mathrm{mol} ; 2 \mu \mathrm{Ci} / 200 \mathrm{~g}$ body wt.) was injected intravenously, and blood samples $(0.5 \mathrm{ml})$ were withdrawn at timed intervals and replaced by an equivalent volume of $0.15 \mathrm{M}-\mathrm{NaCl}$. After deproteinization (Weichselbaum \& Somogyi, 1941), the samples were passed through a column $(0.5 \mathrm{~cm} \times 4 \mathrm{~cm})$ of Dowex AG $1 \mathrm{X8}\left(\mathrm{Cl}^{-}\right.$form), which was washed with $3 \mathrm{ml}$ of water. The eluate, containing radioactive glucose and fructose, was further treated as described by Hue et al. (1978) to separate the remaining fructose from the radioactive glucose.

Clofibrate feeding (Van Hoof et al., 1985) was maintained for 1 month.

For estimation of the rate of gluconeogenesis from lactate in vivo, a tracer dose of [U-14 C]lactate $(5 \mu \mathrm{Ci} / \mathrm{kg}$ body wt.) was injected intravenously to anaesthetized rats, and a blood sample was rapidly taken from the vena cava $2 \mathrm{~min}$ after the injection. The sample was deproteinized with $\mathrm{HClO}_{4}$, and the neutralized supernatant was applied to a column $(0.5 \mathrm{~cm} \times 4 \mathrm{~cm})$ of Dowex AG $1 \times 8\left(\mathrm{Cl}^{-}\right.$form), which was washed with $3 \mathrm{ml}$ of water. The eluate contained the radioactive glucose formed. Lactate and pyruvate were eluted from the column with $3 \mathrm{ml}$ of $1 \mathrm{M}-\mathrm{NaCl}$. The concentrations and the radioactivities of glucose and lactate were measured in both eluates. The amount of lactate converted into glucose in $2 \mathrm{~min}$ was calculated from these data by dividing the radioactivity in glucose by the specific radioactivity of lactate at $2 \mathrm{~min}$. Two assumptions were made, namely that there was instantaneous equilibrium of the newly formed glucose with the pool of pre-existing glucose and that there was no utilization of the newly formed glucose during the $2 \mathrm{~min}$ period.

\section{Experiments with isolated hepatocytes}

Hepatocytes were prepared and incubated as described by Hue et al. (1978). Other specific conditions are detailed where appropriate.

\section{Enzyme assays and analytical methods}

Except where otherwise stated, glucose-6-phosphatase and glucokinase (Bontemps et al., 1978) were measured under $V_{\max }$. conditions. The activity of cyclic AMP-
Table 1. Effect of hypoglycin on blood glucose concentration, body temperature and on the concentrations of several metabolites in rat liver

Rats were given hypoglycin $(70 \mathrm{mg} / \mathrm{kg}$ body wt.) $16 \mathrm{~h}$ before death. The values are means for three rats in control group and four in the treated group: *denotes values that are statistically different from the control $(P<0.05)$.

\begin{tabular}{lcc}
\hline & $\begin{array}{c}\text { Control } \\
\text { rats }\end{array}$ & $\begin{array}{c}\text { Hypoglycin- } \\
\text { treated } \\
\text { rats }\end{array}$ \\
\hline Body temperature $\left({ }^{\circ} \mathrm{C}\right)$ & $36.2 \pm 0.3$ & $28.2 \pm 1.1^{*}$ \\
Blood glucose $(\mu \mathrm{mol} / \mathrm{ml})$ & $5.3 \pm 0.4$ & $1.5 \pm 0.7^{*}$ \\
ATP $(\mu \mathrm{mol} / \mathrm{g})$ & $3.6 \pm 0.3$ & $2.9 \pm 0.7$ \\
Glucose 6-phosphate & $91 \pm 8$ & $51 \pm 9^{*}$ \\
$(\mathrm{nmol} / \mathrm{g})$ & & \\
\hline
\end{tabular}

dependent protein kinase was measured with histone as substrate in the presence or absence of $10 \mu \mathrm{M}$-cyclic AMP (van de Werve et al., 1977). The activity is expressed as the ratio of the activity in the absence of cyclic AMP divided by the activity in the presence of $10 \mu \mathrm{M}$-cyclic AMP. The active form of phosphorylase $a$ was assayed as described by Hue et al. (1975). Pyruvate kinase activity was assayed at $0.15 \mathrm{~mm}$ - and $5 \mathrm{~mm}$-phosphoenolpyruvate (Feliu et al., 1976); the activity ratio at these two substrate concentrations $\left(v_{0.15} / V_{5}\right)$ gives an estimation of the activation state of the enzyme (Feliu et al., 1977). The enzyme activities were measured at room temperature, except for glucose-6-phosphatase, which was measured at $37^{\circ} \mathrm{C}$.

To detect an inhibition of glucose-6-phosphatase activity by endogenous metabolite(s), an assay was set up to measure glucose-6-phosphatase activity radiochemically in homogenates prepared with a minimal volume. Livers were homogenized in 2 vol. of $0.1 \mathrm{M}-\mathrm{KCl} / 0.02 \mathrm{M}-$ glycylglycine, $\mathrm{pH} 7.4$. Samples $(0.15 \mathrm{ml})$ of homogenates were incubated in a final volume of $0.2 \mathrm{ml}$, for $0,2,5$ and $10 \mathrm{~min}$ in the presence of $\left[\mathrm{U}-{ }^{14} \mathrm{C}\right]$ glucose 6-phosphate (40000 c.p.m./test) at the indicated concentration. The activity was assayed at $10^{\circ} \mathrm{C}$ in order to decrease the activity of glucose-6-phosphatase, which otherwise would be too large. The reaction was stopped by the addition of $0.5 \mathrm{ml}$ of $\mathrm{ZnSO}_{4}$ and $\mathrm{Ba}(\mathrm{OH})_{2} ; 0.8 \mathrm{ml}$ of water was added and the radioactivity of $1 \mathrm{ml}$ of the supernatant was measured. Under these conditions, the barium precipitate contained $95-98 \%$ of the unchanged glucose 6-phosphate, depending on the batch of the radioactive substrate. The proportion of the substrate hydrolysed during the reaction did not exceed $25-30 \%$ of the initial amount, and the rate was linear with time.

Glucose (Huggett \& Nixon, 1957), glucose 6-phosphate (Hohorst, 1963), pyruvate and phosphoenolpyruvate (Czok \& Lamprecht, 1974) and ATP (Lamprecht \& Trautschold, 1963) were measured enzymically in neutralized $\mathrm{HClO}_{4}$ extracts.

\section{RESULTS}

\section{Experiments in whole animals}

After the administration of hypoglycin, the rats were all behaviourally depressed, hypoglycaemic and hypothermic, although there was some variation in the 
Table 2. Effect of administration of hypoglycin on the activity of liver glucokinase, glucose-6-phosphatase, glycogen phosphorylase, pyruvate kinase and cyclic AMPdependent histone kinase

Rats were given hypoglycin $(70 \mathrm{mg} / \mathrm{kg}$ body wt.) $16 \mathrm{~h}$ before death. Glucokinase and glucose-6-phosphatase were measured under $V_{\max }$. conditions. The values are means \pm S.E.M. for at least three rats; ${ }^{*}$ denotes values that are statistically different from the control $(P<0.05)$.

\begin{tabular}{lcc}
\hline & Control rats & $\begin{array}{c}\text { Hypoglycin- } \\
\text { treated rats }\end{array}$ \\
\hline $\begin{array}{c}\text { Glucokinase } \\
\text { (unit/g of liver) }\end{array}$ & $0.77 \pm 0.03$ & $0.80 \pm 0.03$ \\
$\begin{array}{c}\text { Glucose-6-phosphatase } \\
\text { (units/g of liver) }\end{array}$ & $17.0 \pm 1.2$ & $16.3 \pm 1.2$ \\
$\begin{array}{c}\text { Phosphorylase } a \\
\text { (units/g of liver) }\end{array}$ & $6.0 \pm 1.3$ & $10.5 \pm 0.7^{*}$ \\
$\begin{array}{c}\text { Pyruvate kinase } \\
\left.\text { (vi.15 } / V_{5}\right)\end{array}$ & $0.25 \pm 0.02$ & $0.15 \pm 0.03^{*}$ \\
$\begin{array}{c}\text { Cyclic AMP-dependent } \\
\text { histone kinase } \\
\text { (activity ratio) }\end{array}$ & $0.36 \pm 0.01$ & $0.71 \pm 0.13^{*}$ \\
\hline
\end{tabular}

severity of the effect (Table 1). Table 1 also shows that, in the livers of hypoglycin-treated rats, the concentration of glucose 6-phosphate was significantly lower than in the controls. ATP concentrations were not statistically different.

The measurement of enzyme activities (Table 2) in livers of rats revealed that, in treated rats, glycogen phosphorylase was in the active form and pyruvate kinase was in the less-active form. These changes in activity could result from the activation of the cyclic AMP-dependent protein kinase, which, in turn, could be due to an increased secretion of glucagon caused by the hypoglycaemic stress. Indeed, a sustained secretion of glucagon was already suggested by the observation of the specific depletion of the granules in the $\alpha$-cells of the pancreatic islets during hypoglycin poisoning (Feng, 1957). Further evidence for this was the measurement of an increased proportion of the cyclic AMP-dependent histone kinase in its active form in the livers of hypoglycaemic rats (Table 2). By contrast, there was no significant difference between the $V_{\text {max }}$. of glucose-6phosphatase and of glucokinase in liver from either group. The activity of glucokinase was also measured at $1 \mathrm{~mm}$ - or $5 \mathrm{~mm}$-glucose and was similar in both groups (results not shown).

Another series of experiments was performed to estimate gluconeogenesis and, especially, to assess the activity of liver glucose-6-phosphatase in vivo. First, we confirmed the previous observation (Osmundsen et al., 1978) that, in hypoglycin-treated rats, the loss of ${ }^{3} \mathrm{H}$ relative to ${ }^{14} \mathrm{C}$ from $\left[2-{ }^{3} \mathrm{H}, \mathrm{U}-{ }^{14} \mathrm{C}\right]$ glucose was almost abolished (results not shown). Second, gluconeogenesis from lactate in vivo was estimated by measuring the radioactive glucose appearing in blood $22 \mathrm{~min}$ after the intravenous injection of $\left[\mathrm{U}-{ }^{14} \mathrm{C}\right]$ lactate into anaesthetized rats. It was calculated that, in two control rats, $1.08 \mu \mathrm{mol}$ of lactate was converted into glucose in $2 \mathrm{~min}$ per $\mathrm{ml}$ of blood, whereas only $0.20 \pm 0.05 \quad(n=3) \mu \mathrm{mol} / 2 \mathrm{~min}$ per $\mathrm{ml}$ was converted in the hypoglycin-treated rats. Because of the assumptions made to calculate these rates

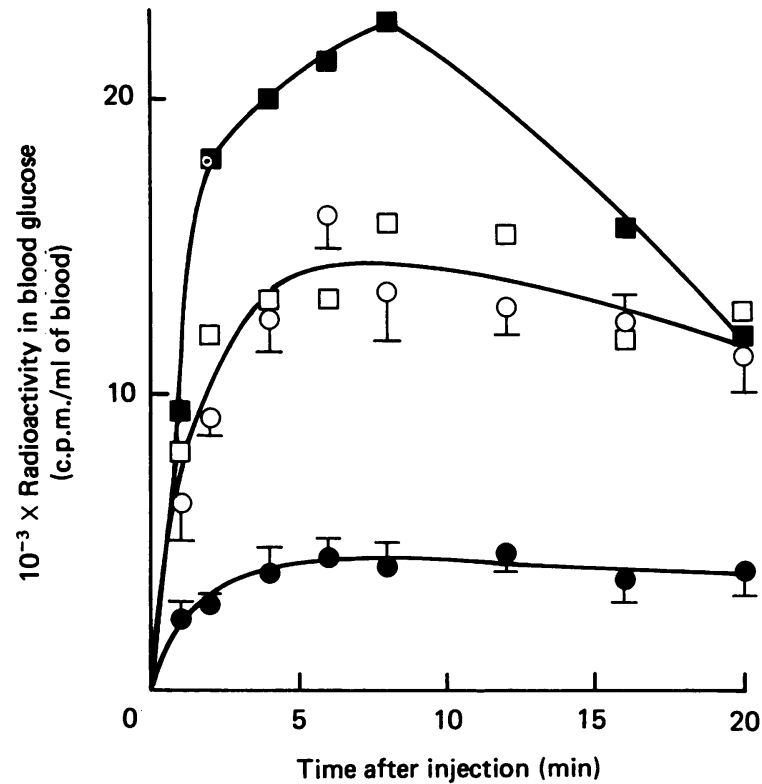

Fig. 1. Time course of the formation of radioactive glucose from $\left[{ }^{14} \mathrm{C}\right]$ fructose in anaesthetized rats

Experimental details are given in the Materials and methods section. The values are means \pm S.E.M. for six rats in the control group $(O)$, four rats in the hypoglycin group (O), and two rats in both the clofibrate group ( $\square$ ) and the clofibrate + hypoglycin group ( $\square$ ). All the values from hypoglycin-treated rats $(O)$ are statistically different from controls $(O)(P<0.05)$.

(see the Materials and methods section), the values represent, at best, a rough estimate of the gluconeogenesis in vivo. In any case, the 5-fold difference between the two groups further documents the inhibition of gluconeogenesis in vivo by hypoglycin.

Finally, the conversion of fructose into glucose in vivo was compared in control and hypoglycin-treated rats. After the intravenous injection of $\left[\mathrm{U}-{ }^{14} \mathrm{C}\right]$ fructose to control anaesthetized rats, labelled fructose readily disappeared from the blood, and a large proportion was converted into glucose (Fig. 1). With hypoglycin-treated rats, the formation of radioactive glucose was several-fold less (Fig. 1), although the rate of disappearance of labelled fructose was not different in the two groups (results not shown). The difference in the formation of glucose is even more striking if one considers that the rate of irreversible disposal of glucose in hypoglycin-treated rats is only $30 \%$ of that in the controls (Osmundsen et al., 1978). Fig. 1 also shows that clofibrate feeding prevents the effect of hypoglycin.

\section{Experiments with hepatocytes}

When hepatocytes from hypoglycin-treated rats were incubated for $30 \mathrm{~min}$ in the presence of $10 \mathrm{~mm}$-glucose, glycogen phosphorylase was in the inactive form and pyruvate kinase was in the active form, presumably because the influence of endogenous glucagon has been lost during the preparation of the hepatocytes. Addition of $1 \mathrm{nM}$-glucagon to hepatocytes from both control and hypoglycin-treated rats resulted in the expected activation of phosphorylase and inactivation of pyruvate kinase. 
Table 3. Effect of hypoglycin and several amino acids on gluconeogenesis in hepatocytes from normal rats

Hepatocytes from normal rats fasted overnight were incubated for $120 \mathrm{~min}$ at $37^{\circ} \mathrm{C}$ (Hue et al., 1978) in the presence of the substrates indicated, $2 \%$ of defatted albumin, $0.25 \mathrm{~mm}$-oleic acid, $0.25 \mathrm{~mm}$-linoleic acid, $1 \mathrm{~mm}$-carnitine and the other additions as indicated. The amino acids added were leucine, isoleucine, lysine and tryptophan, each at $1 \mathrm{mM}$. The values are means \pm S.E.M. for three different cell preparations, or means of two cell preparations when no S.E.M. value is given: ${ }^{*}$ denotes value that is statistically different from the control incubated without addition $(P<0.05)$.

\begin{tabular}{|c|c|c|}
\hline \multirow[b]{2}{*}{$\begin{array}{l}\text { Substrates ... } \\
\text { Additions }\end{array}$} & \multicolumn{2}{|c|}{$\begin{array}{l}\text { Rate of glucose production } \\
\text { ( } \mu \text { mol of glucose/min per } \mathrm{g} \\
\text { of cells) }\end{array}$} \\
\hline & $10 \mathrm{~mm}$-Pyruvate & $\begin{array}{c}10 \mathrm{~mm} \text {-Pyruvate }+ \\
10 \mathrm{~mm} \text {-fructose }\end{array}$ \\
\hline $\begin{array}{l}\text { None } \\
5 \text { mM-hypoglycin } \\
1 \mathrm{~mm} \text { amino acids } \\
5 \mathrm{~mm} \text {-hypoglycin }+ \\
1 \mathrm{~mm} \text { amino acids }\end{array}$ & $\begin{array}{l}0.76 \pm 0.06 \\
0.48 \pm 0.03^{*} \\
0.31 \\
0.20\end{array}$ & $\begin{array}{l}1.50 \pm 0.18 \\
1.62 \pm 0.22 \\
1.31 \\
1.29\end{array}$ \\
\hline
\end{tabular}

Since the effect of hypoglycin treatment on phosphorylase and pyruvate kinase was lost during the preparation of hepatocytes, it was important to check whether the inhibition of glucose recycling persisted in the hepatocyte preparation. One rat was treated with hypoglycin for $26 \mathrm{~h}$ and injected with $\left[2-{ }^{3} \mathrm{H}, \mathrm{U}-{ }^{14} \mathrm{C}\right]$ glucose after $24 \mathrm{~h}$. The ${ }^{3} \mathrm{H} /{ }^{14} \mathrm{C}$ ratio in blood glucose $60 \mathrm{~min}$ after injection was $88 \%$ of its initial value, i.e. much higher than in the controls $(55 \%)$. Hepatocytes were then prepared and recycling of $5 \mathrm{~mm}-\left[2-{ }^{3} \mathrm{H}, \mathrm{U}-{ }^{14} \mathrm{C}\right]$ glucose was measured. The rate was $28.6 \mu \mathrm{mol} / \mathrm{h}$ per $\mathrm{g}$ of protein and not different from the rates of control hepatocytes $(28.7 \mu \mathrm{mol} / \mathrm{h}$ per $\mathrm{g})$.

It was also confirmed that, in hepatocytes from normal rats, the addition of hypoglycin caused an inhibition of glucose formation from lactate, but not from fructose (Table 3). The effects of hypoglycin are complex, and it is known that isovalerate, 2-methylbutyrate, glutarate and various unsaturated dicarboxylic acids accumulate in vivo as the result of the impaired metabolism of leucine, isoleucine, tryptophan, lysine and long-chain fatty acids (Tanaka, 1972). To mimic these conditions, hepatocytes were incubated with or without hypoglycin and in the presence of these amino acids, oleate, linoleate and L-carnitine. In all cases there was no inhibition by hypoglycin of the conversion of fructose into glucose, although glucose synthesis from pyruvate was inhibited. Thus we have been unable to observe an inhibition of glucose-6-phosphatase by hypoglycin in hepatocytes.

\section{Activity of glucose-6-phosphatase in concentrated homogenates}

Since hypoglycin appeared to induce an inhibition of glucose 6-phosphatase in vivo, but not in hepatocytes, it was decided to search for an inhibitor of glucose-6phosphatase in concentrated homogenates of livers from rats treated with hypoglycin. The results show that in concentrated homogenates from hypoglycin-treated rats the activity of glucose-6-phosphatase was twice as

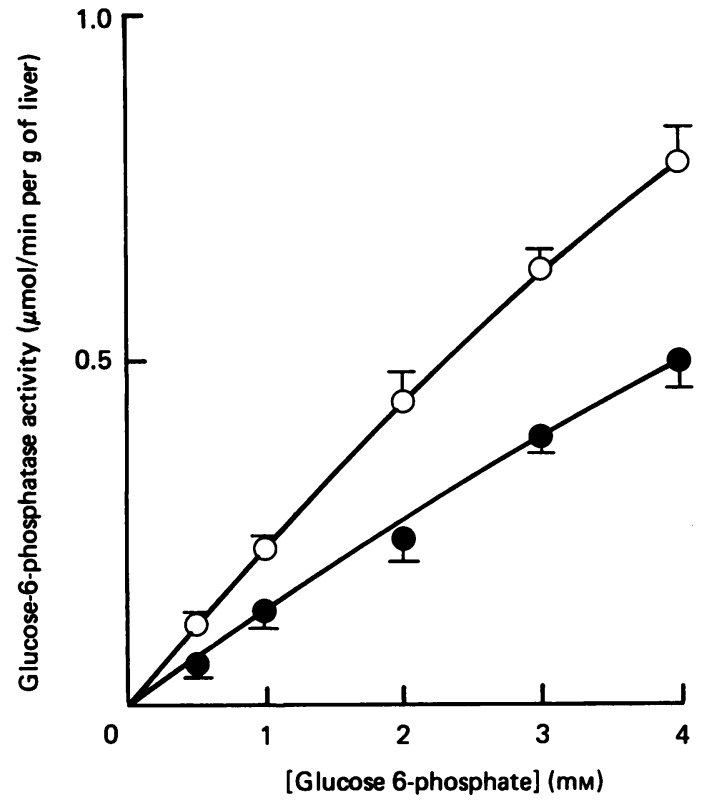

Fig. 2. Glucose-6-phosphatase activity in homogenates of livers from control and hypoglycin-treated rats

Glucose-6-phosphatase activity was measured radiochemically in concentrated homogenates as described in the Materials and methods section. The values are means \pm S.E.M. for three control $(O)$ and four hypoglycin-treated rats $(O)$. All the values from hypoglycin-treated rats are statistically different from the controls $(P<0.05)$.

low as in control homogenates (Fig. 2). It has not been possible to identify the factor responsible for this inhibition.

\section{DISCUSSION}

The administration of hypoglycin in vivo abolishes the relative detritiation of $\left[2-{ }^{3} \mathrm{H}, \mathrm{U}-{ }^{14} \mathrm{C}\right]$ glucose (Osmundsen et al., 1978). Relative detritiation requires the presence of an active glucose-6-phosphatase, and impairment may result from inhibition of the Cori cycle and/or of the glucose/glucose 6-phosphate cycle (Hue, 1981). Since hypoglycin poisoning abolished the difference between the rate of irreversible disposal of $\left[2-{ }^{3} \mathrm{H}\right]$ glucose and $\left[{ }^{14} \mathrm{C}\right]$ glucose (Osmundsen et al., 1978), it necessarily follows that, at least, the glucose/glucose 6-phosphate cycle was inhibited. Since the conversion of radioactive fructose into glucose was also inhibited after hypoglycin (the present paper), it is therefore suggested that a common step in the metabolism of these two sugars, namely the hydrolysis of glucose 6-phosphate, is inhibited in vivo. However, because of hepatic heterogeneity, the conversion of fructose into glucose could have involved an intra-hepatic Cori cycle, and pyruvate could be an obligatory intermediate in the conversion of fructose into glucose. The evidence accumulated so far in the literature strongly argues against this interpretation. The main arguments are the following: (i) the rate of conversion of fructose into glucose is severalfold that of lactate or pyruvate, indicating that the steps between pyruvate and phosphoenolpyruvate are 'rate-limiting' for substrates entering the pathway at the level of pyruvate; (ii) inhibitors of phosphoenolpyruvate carboxykinase inhibit gluconeogenesis from substrates entering the pathway at the level of pyruvate, but not at the level 
of triose phosphates; (iii) factors such as glucagon, which are known to decrease both pyruvate kinase activity and flux, do not inhibit, but rather stimulate, the conversion of fructose into glucose.

Therefore, our results and those of Osmundsen et al. (1978) provide indirect and circumstantial evidence for the inhibition of glucose-6-phosphatase by hypoglycin. This conclusion is also supported by the demonstration of the inhibition of glucose-6-phosphatase activity in concentrated, but not dilute, liver homogenates. However, these data do not demonstrate that the inhibition of glucose-6-phosphatase is solely responsible for the block in gluconeogenesis by hypoglycin. We believe that inhibition of glucose-6-phosphatase participates in the mechanism, and that other enzymes (e.g. pyruvate carboxylase) may be involved in the overall phenomenon. In addition, the fall in glucose 6-phosphate concentration in livers of poisoned rats may indicate that the inhibition of the gluconeogenic pathway is stronger than that of glucose-6-phosphatase.

The inhibition of glucose-6-phosphatase is readily reversible, since the conversion of fructose into glucose was unimpaired in hepatocytes from hypoglycin-treated rats. This suggests that the factor responsible for the inhibition in vivo was either washed out or destroyed during the preparation of hepatocytes. This factor does not appear to be formed when hepatocytes are incubated with hypoglycin, nor does it appear when the incubation medium contained amino acids and long-chain fatty acids. We can conclude that the putative inhibitor is not formed from these substances and that it could be formed in extra-hepatic tissues. Furthermore, it has not been possible to demonstrate any inhibition of glucose-6phosphatase activity in diluted homogenates of livers from poisoned animals (Table 2; Feng \& Patrick, 1958).

Glucose-6-phosphatase is located on the luminal surface of the endoplasmic reticulum, and a specific carrier is needed to transport glucose 6-phosphate to the enzyme (Arion et al., 1975). Inhibition by hypoglycin may be due to impairment of this carrier. This location of glucose-6-phosphatase prevents its inhibition by compounds such as ATP (Nordlie, 1974). Another possibility is that during hypoglycin poisoning the permeability of the endoplasmic reticulum is reversibly modified so that such cytosolic inhibitors gain access to glucose-6-phosphatase.

In rats given the hypolipidaemic drug clofibrate, there was no inhibition by hypoglycin of the conversion of fructose into glucose. Clofibrate feeding also prevents the toxic, hypoglycaemic and hypothermic effects of hypoglycin (Van Hoof et al., 1985).

Although hypoglycaemia caused by hypoglycin is characterized by severe depletion of hepatic glycogen (see Sherratt, 1969), paradoxically the inhibition of glucose6-phosphatase in vivo may be a model for Type-1bis glycogen-storage disease. In this disease, the liver displays normal activities of glucose-6-phosphatase in dilute homogenates metabolism (Hue, 1981). In these patients, however, the activity of glucose-6-phosphatase, as measured in vivo by the rate of detritiation of glucose, is abnormally low. It may be that an inborn error of metabolism causes the formation of a product which acts in the liver to inhibit glucose-6-phosphatase in a manner analogous to that postulated in hypoglycin poisoning.
We thank B. de Spot for typing the manuscript. This work was supported by the Belgian Fonds de la Recherche Scientifique Médicale and the U.S. Public Health Service. L.H. is Maître de Recherches of the Belgian Fonds National de la Recherche Scientifique. H.S.A.S. thanks the Royal Society for the award of a European Science Exchange Programme Fellowship.

\section{REFERENCES}

Arion, W. J., Wallin, B. K., Lange, A. J. \& Ballas, L. M. (1975) Mol. Cell. Biochem. 6, 75-83

Billington, D. \& Sherratt, H. S. A. (1981) Methods Enzymol. 72, 610-616

Bontemps, F., Hue, L. \& Hers, H. G. (1978) Biochem. J. 174, 603-611

Czok, R. \& Lamprecht, W. (1974) in Methods of Enzymatic Analysis (Bergmeyer, H. U., ed.), pp. 1446-1451, Academic Press, New York

Feliu, J. E., Hue, L. \& Hers, H. G. (1976) Proc. Natl. Acad. Sci. U.S.A. 73, 2762-2766

Feliu, J. E., Hue, L. \& Hers, H. G. (1977) Eur. J. Biochem. 81, 609-617

Feng, P. C. (1957) Nature (London) 180, 855-856

Feng, P. C. \& Patrick, S. J. (1958) Br. J. Pharmacol. Chemother. 13, 125-130

Hohorst, H. J. (1983) in Methods of Enzymatic Analysis (Bergmeyer, H. U., ed.), pp. 134-138, Academic Press, New York and London

Hue, L. (1981) Adv. Enzymol. 52, 247-331

Hue, L. \& Hers, H. G. (1974) Biochem. Biophys. Res. Commun. 58, 532-539

Hue, L., Bontemps, F. \& Hers, H. G. (1975) Biochem. J. 152, 105-114

Hue, L., Feliu, J. E. \& Hers, H. G. (1978) Biochem. J. 176, 791-797

Huggett, A. St. G. \& Nixon, D. A. (1957) Biochem. J. 66, 12P

Katz, J. \& Rognstad, R. (1976) Curr. Top. Cell. Regul. 10, 237-289

Lamprecht, W. \& Trautschold, I. (1963) in Methods of Enzymatic Analysis (Bergmeyer, H. U., ed.), pp. 543-551, Academic Press, New York and London

Nordlie, R. C. (1974) Curr. Top. Cell. Regul. 8, 33-117

Osmundsen, H., Billington, D., Taylor, J. R. \& Sherratt, H. S. A. (1978) Biochem. J. 170, 337-342

Scrutton, M. C. \& Griffiths, J. R. (1981) in Short-Term Regulation of Liver Metabolism (Hue, L. \& van de Werve, G., eds.), pp. 175-198, Elsevier, Amsterdam

Sherratt, H. S. A. (1969) Br. Med. Bull. 25, 250-255

Sherratt, H. S. A. (1981) in Short-Term Regulation of Liver Metabolism (Hue, L. \& van de Werve, G., eds.), pp. 199-227, Elsevier, Amsterdam

Sherratt, H. S. A., Bartlett, K. \& Turnbull, D. M. (1985) in The Pharmacological Effects of Lipids II: AOCS Monogr. 13 (Kabarra, J. J., ed.), pp. 247-262, American Oil Chemists Society, Chámpaign American Oil

Stirk, J. H., Bartlett, K. \& Sherratt, H. S. A. (1983) Biochem. Soc. Trans. 11, 285-287

Tanaka, K. (1972) J. Biol. Chem. 247, 7465-7478

van de Werve, G., Stalmans, W. \& Hers, H. G. (1977) Biochem. J. 162, 143-146

Van Hoof, F., Hue, L., de Barsy, T., Jacquemin, P., Devos, P. \& Hers, H. G. (1972) Biochimie 54, 745-751

Van Hoof, F., Hue, L., Vamecq, J. \& Sherratt, H.S.A. (1985) Biochem. J. 229, 387-397

Weichselbaum, T. E. \& Somogyi, M. (1941) J. Biol. Chem. 140, 5-20

Wollenberger, A., Ristau, O. \& Schoffa, G. (1960) Pflügers Arch. Gesamte Physiol. Menschen Tiere 270, 399-412 